\title{
Techniques and tools of lean production: multiple case studies in brazilian agribusiness units
}

\section{Técnicas e ferramentas do lean production: estudos de múltiplos casos em empresas do agronegócio brasileiro}

\author{
Eduardo Guilherme Satolo ${ }^{1}$ (D), Laiz Eritiemi de Moura Hiraga ${ }^{1}$ (D), Lucas Furlani Zoccal ${ }^{1}$ (D), \\ Gustavo Antiqueira Goes ${ }^{1}$ (D), Wagner Luiz Lourenzani ${ }^{1}$ (D), Pedro Henrique Perozini ${ }^{1}$ \\ ${ }^{1}$ Universidade Estadual Paulista - UNESP, Faculdade de Ciências e Engenharia, Tupã, SP, Brasil. \\ E-mail: eduardo.satolo@unesp.br; laizhiraga@hotmail.com; lucaszoccal@tupa.unesp.br; \\ gustavogoes@tupa.unesp.br; wagner.lourenzani@unesp.br; pedroperozini@gmail.com
}

How to cite: Satolo, E. G., Hiraga, L. E. M., Zoccal, L. F., Goes, G. A., Lourenzani, W. L., \& Perozini, P. H. (2020). Techniques and tools of lean production: multiple case studies in brazilian agribusiness units. Gestão \& Produção, 27(1), e3252. https://doi.org/10.1590/0104-530X3252-20

\begin{abstract}
The literature regarding Lean Production philosophy is vast depicting historical aspects, implementation challenges, benefits of its adoption and other topics applied to various industries and services. However, the agribusiness segment, one of the major segments of the global economy features a large gap in national and international literature. This article aims to conduct a research through multiple case studies concerning the use of techniques and tools of Lean Production System in agribusiness organizations. Multiple type case studies were conducted in eight agribusiness units from different segments through the application of structured interviews, on site visits and document analysis. The research carried has identified that Lean Production techniques and tools are applicable to agribusiness environments, and that the ones which involve improvements in process control, production flow and logistics have higher emphasis on research units. Techniques and tools such as long-term supplier and customer relationship, production smoothing/heijunka and value stream mapping distinguished themselves by the similarity of use when compared to previous studies in agribusiness environment. It was also identified that there are differences concerning the adoption of the techniques and tools in research units that operate in production environments of the type Make to Order or Make to Stock. Such differences are imposed by specificities that affect agribusiness organizations, which is indicative for future studies.
\end{abstract}

Keywords: Lean manufacturing; Multiple case studies; Brazil; Agribusiness; Network analysis.

Resumo: A literatura acerca da filosofia Lean Production é vasta retratando aspectos históricos, desafios da implantação, benefícios da sua adoção e outros tópicos aplicados aos diversos segmentos industriais e de serviços. Entretanto, no segmento do agronegócio, um dos principais segmentos da economia mundial, apresenta uma grande lacuna na literatura nacional e internacional. Este artigo objetiva conduzir um levantamento, por meio de estudos de caso múltiplos, sobre o emprego das técnicas e ferramentas do sistema Lean Production em organizações do agronegócio. Conduziu-se estudos de caso do tipo múltiplo em oito unidades agroindustriais de diferentes segmentos, por meio da aplicação de entrevistas estruturadas, visita in loco e análise documental. O estudo identificou que as técnicas e ferramentas do sistema Lean Production são aplicáveis no ambiente agroindustrial, sendo as de maior destaque para as

Received June 13, 2016 - Accepted Nov. 6, 2016

Financial support: Grant 2013/21047-5, São Paulo Research Foundation (FAPESP)

This is an Open Access article distributed under the terms of the Creative Commons Attribution License, which permits unrestricted use, distribution, and reproduction in any medium, provided the original work is properly cited. 
unidades de pesquisa que envolvem melhorias no controle do processo, fluxo de produção e logística. Técnicas e ferramentas como long-term supplier and customer relationship, production smoothing/heijunka, e value stream mapping destacaram por pela similaridade de uso quando comparados a estudos prévios no ambiente agroindustrial. Identificou-se também que há diferenças quanto a adoção das técnicas e ferramentas em unidades de pesquisa que atuam em ambientes de produção Make to Order ou Make to Stock. Tais diferenças são impostas pelas especificidades que afetam as organizações do agronegócio, sendo este o indicativo para estudos futuros.

Palavras-chave: Lean manufacturing; Estudos de caso múltiplo; Brazil; Agronegócio; Análise de redes sociais.

\section{Introduction}

It was noted in recent years that business environment has experienced significant changes in national and global level. Globalization and the inherent technological improvements have been redefined determinant factors of competitiveness, bringing out new success organizations and turning obsolete those unable to adapt to new surroundings (Savic et al., 2014).

Such optimization scenario of organizational environments has intensified the demand for higher speed in product development, manufacturing flexibility, waste elimination, better process control and the use of efficient workforce (Karim \& Arif-Uz-Zaman, 2013). The establishment of leaner and more flexible organizational structures linked to a systemic approach strongly associated with cost reduction through waste elimination is essential.

This adaptation to new market strategies in various industrial sectors has been given by what is called Lean Production System that was originated by the Toyota Production System. In this production system a management model was developed and became an effective and competitiveness reference.

The Lean Production System has a philosophy that aims to identify and minimize or phasing out sources of waste based on five key principles: the definition of (i) value from the customer view and their needs, that determines (ii) the value chain, which are required activities to offer the product to the customer with the lowest level of wastage. Then the product is manufactured using a (iii) continuous flow, which is triggered only when the client performs the request. That is, using the logic of (iv) pull production. Based on these four principles and the use of continuous improvement (kaizen) or radical improvements (kaikaku) the fifth fundamental principle is reached, which is the (v) system perfection (Calarge et al., 2012).

According to Chiarini (2014), the implementation of Lean Production System within organizations is linked directly to the use of techniques and tools which are constantly analyzed by researchers.

It is possible to find studies based on the application of Lean Production techniques and tools in authors such as Feld (2001), Pettersen (2009), Walter \& Tubino (2013), Marodin \& Saurin (2013), Calarge et al. (2012), Bhamu \& Sangwan (2014), Vamsi Krishna Jasti \& Kodali (2014) and Savic et al. (2014). However, it is noted that the agribusiness segment, although it has high importance for the global economy, has been little explored by researchers when interconnected with Lean Production.

The agribusiness, according to Zylberstajn (2013), was created to designate the inseparable connection between the agricultural production activity and industrial 
activity, both the inputs to it addressed, either to the processing of production it has generated.

Gunderson et al. (2014) adds that for an efficient and effective operation of agribusiness companies its require an understanding and assessment of, for example, costs and components cost, product and work force flow scheduling and logistics, inventory management, sales and customer relationship management, selecting and managing the workforce, capital access, and financial management.

The various techniques and tools developed and assimilated by Lean Production system allow to meet to the various aspects indicated by Gunderson et al. (2014). However, according to Karim \& Arif-Uz-Zaman (2013), these many Lean tools available may not fit to all organizations and manufacturing processes.

The authors appoint the selection of Lean tools greatly depend on particular manufacturing process of a particular organization. So, the consideration of organizational contexts has largely been ignored in research on implementation of Lean strategies. As a result, in many cases Lean implementation resulted in increase in waste, cost and production time of a manufacturer.

It should be noted that in these particularities of organizational environment, agribusiness is located within an environment called by the authors (Barnard et al., 2016; Gunderson et al., 2014; Batalha \& Silva, 2008) as unique by its distinct characteristics to other sectors, and by specificities of its production and unique commercialization.

Furthermore, it does distinct from other sectors by dealing directly with raw materials and processed products of high perishability, adding up seasonal variations that affect demand and consumption, and also by the constant vigilance and zeal for quality, among others.

In literature there are few studies that depict the theme of Lean Production focused on the agribusiness environment. In bibliometric review papers regarding Lean, authors such as Vamsi Krishna Jasti \& Kodali (2014), Bhamu \& Sangwan (2014) and Marodin \& Saurin (2013) identified an average of $3 \%$ of papers that turn their study to the Lean application on agribusiness environment.

Within this scenario is identified a gap in literature that motivates this research. It is about the lack of studies that demonstrate the state of the art regarding the application of Lean Production concepts closer to the agribusiness segment

Thus, this paper aims to conduct a research through multiple case studies on the use of techniques and tools of Lean Production System in agribusiness organizations in order to confront the specific literature and identify opportunities to further developments for researches.

The paper is presented as an original contribution to management operations and similar areas, because it highlights data from eight case studies in different agribusiness segments and compare them with specific literature about Lean Production System. Thus, it demonstrates topics that converge and diverge with traditional areas of application of this theory.

This article is divided into four sections to present the results. This first section presents the research contextualization and the gap holding up its achievement. The second section presents a brief theoretical background about the concept of Lean Prodution System and the use of techniques and tools used in its implementation. The third section presents the research method and its stages. The fourth section presents the results of the bibliographical research on Lean Production System applied 
in agribusiness companies, as well as a critical analysis thereof, substantiated through the literature review. Finally, the article ends with the fifth section presenting the conclusions and perspectives for future studies.

\section{Foundation of Lean Production Systems}

The Toyota Production System (TPS) appeared at the end of the Second World War, when the Japanese industry had to rethink their production model due to the shortage of productive resources. This system aims to produce with the lowest possible cost, especially by combating the so-called wastage (Lucato et al., 2014).

But the term Lean Production was defined in late 1980s in a research project at Massachusetts Institute of Technology (MIT), which studied the global automotive industry, with the main focus on the Japanese Toyota model in order to map out the best industry practices. This study was carried out by means of interviews with employees, trade unionists and government officials. The study showed the remarkable superiority of Toyota related to product development and relationships with customers and suppliers due to the new concept of management system, called the Toyota Production System (Stone, 2012).

Several publications, books and periodicals cover the concepts of the Lean Production System helping the popularization of its philosophy, especially the following publications: Ohno (1988), Shingo (1989) and Womack et al. (2008). Since then, the Lean concept has become an area of academic interest due to its dissemination in a wide range of industries and countries, particularly in operations management (Chiarini \& Vagnoni, 2014).

\subsection{Techniques and tools of Lean Production Systems}

The implementation of Lean Production System in organizations uses various techniques and tools, which should take place in a coordinated and structured way (Pettersen, 2009; Chiarini, 2014)

Organizations, regardless of its size or sector, have been adopting the Lean philosophy (Hu et al., 2015) and the use of techniques and tools in order to improve productivity and waste elimination (Belekoukias et al., 2014). Such practices aim the optimization of production processes and the elimination of times that do not add value to the product (Pakdil \& Leonard, 2014).

This waste minimization or elimination (MUDA in Japanese) is classified into seven types, namely: overproduction, waiting, transportation, motion, over processing, rework and inventory (Vinodh et al., 2013).

These techniques and tools assist this process of minimization or waste elimination by bringing results such as: reducing lead times, cost savings, quality improvement and increased productivity, making them agile and more competitive (Sharma et al., 2015; Karim \& Arif-Uz-Zaman, 2013).

Feld (2001) adds that it is possible to group the techniques and tools in five major categories, as described in Table 1. 
Table 1. Five categories of techniques and tools of Lean Production System by Feld (2001).

\begin{tabular}{|c|c|c|}
\hline Category & Description & Techniques and Tools \\
\hline $\begin{array}{l}\text { Manufacturing } \\
\text { Flow }\end{array}$ & $\begin{array}{l}\text { Covers techniques related to } \\
\text { physical exchanges, product } \\
\text { development procedures and } \\
\text { definition of necessary } \\
\text { standards. }\end{array}$ & $\begin{array}{l}\text { - Value Stream Mapping (VSM); } \\
\text { - Customization; } \\
\text { - Takt time concept; } \\
\text { - Cellular layout organization, among } \\
\text { others. }\end{array}$ \\
\hline $\begin{array}{l}\text { Organization } \\
\text { and culture }\end{array}$ & $\begin{array}{l}\text { Adds up techniques and tools } \\
\text { related to the definition of the } \\
\text { individuals' roles, learning, } \\
\text { communication and common } \\
\text { values. }\end{array}$ & $\begin{array}{l}\text { - Organization for multifunctional } \\
\text { teams; } \\
\text { - Empowerment; } \\
\text { - Definition of mission and values of the } \\
\text { organization, among others. }\end{array}$ \\
\hline Process control & $\begin{array}{l}\text { Discuss techniques related to } \\
\text { tracking, monitoring, control, } \\
\text { stabilization and improvement } \\
\text { of the production process. }\end{array}$ & $\begin{array}{l}\text { - SPC (Statistical Process Control); } \\
\text { - SMED (Single Minute Exchange of } \\
\text { Die); } \\
\text { - 5S Program; } \\
\text { - TPM (Total Productive Maintenance); } \\
\text { - Poka Yoke, among others. }\end{array}$ \\
\hline Metrics & $\begin{array}{l}\text { Techniques that measure the } \\
\text { performance improvement } \\
\text { goals and actions, recognition } \\
\text { for work teams and } \\
\text { employees. }\end{array}$ & $\begin{array}{l}\text { - Cycle time } \\
\text { - Inventory turns } \\
\text { - Value added per worker, among } \\
\text { others. }\end{array}$ \\
\hline Logistics & $\begin{array}{l}\text { Relates operating rules, } \\
\text { planning and control methods } \\
\text { of internal and external } \\
\text { material flows. }\end{array}$ & $\begin{array}{l}\text { - JIT (Just in Time), } \\
\text { - Kanban } \\
\text { - ABC classification, among others. }\end{array}$ \\
\hline
\end{tabular}

Source: Prepared by the authors.

It is added that in the concept of Lean Production System any classification structure is taken as definitive, which means that techniques and tools can be inserted according to the technological and competitive needs required by the organization.

In recent studies, Vamsi Krishna Jasti \& Kodali (2014) gathered, in a single material, 178 empirical papers published between 1993 and 2009. From this total, only $2.8 \%$ of them carried out studies in an agribusiness environment. In a similar study, Bhamu \& Sangwan (2014) evaluated 209 publications from 1988 to 2013 and identified a set of publications in which $3.8 \%$ of these were related to researches in agribusiness environments. Finally, Marodin \& Saurin (2013) evaluated 102 articles between 1996 and 2012 , with $3.9 \%$ of these addressed the Lean practices in agribusiness.

Furthermore, authors detected the frequency of use of the Lean Production techniques and tools by organizations. Thus, it is possible to establish the percentage of use of them in various organizational environments. This result is illustrated in Table 2 and the five main techniques and tools identified for each study are highlighted in gray. 
Table 2. Percentage of use of the Lean Production techniques and tools considering studies from Vamsi Krishna Jasti \& Kodali (2014), Bhamu \& Sangwan (2014) and Marodin \& Saurin (2013).

\begin{tabular}{|c|c|c|c|}
\hline \multirow[b]{2}{*}{ Techniques and Tools } & \multicolumn{3}{|c|}{ Authors } \\
\hline & $\begin{array}{c}\text { Vamsi } \\
\text { Krishna Jasti } \\
\text { \& Kodali } \\
\text { (2014) }\end{array}$ & $\begin{array}{c}\text { Bhamu \& } \\
\text { Sangwan } \\
(2014)\end{array}$ & $\begin{array}{c}\text { Marodin \& } \\
\text { Saurin (2013) }\end{array}$ \\
\hline $5 S$ & 15.2 & 11.0 & 5.9 \\
\hline Autonomation/Jidoka & $\mathrm{N} / \mathrm{I}^{*}$ & 3.3 & 9.9 \\
\hline Cellular manufacturing/(GT) & $\mathrm{N} / \mathrm{I}^{*}$ & 9.6 & 10.9 \\
\hline Concurrent engineering & $\mathrm{N} / \mathrm{I}^{*}$ & $\mathrm{~N} / \mathrm{I}^{*}$ & 5.0 \\
\hline Continuous flow & 15.2 & $\mathrm{~N} / \mathrm{I}^{*}$ & 9.9 \\
\hline Customer involvement & 14.6 & $\mathrm{~N} / \mathrm{I}^{*}$ & 5.0 \\
\hline Employee commitment & 14.0 & $\mathrm{~N} / \mathrm{I}^{*}$ & $\mathrm{~N} / \mathrm{I}^{*}$ \\
\hline Flexible information system & 15.7 & $\mathrm{~N} / \mathrm{I}^{*}$ & $\mathrm{~N} / \mathrm{I}^{*}$ \\
\hline Just in time production & 16.3 & 16.3 & $\mathrm{~N} / \mathrm{I}^{*}$ \\
\hline Just in time purchasing & 19.1 & $\mathrm{~N} / \mathrm{I}^{*}$ & 3.0 \\
\hline Kaizen & 28.1 & 16.3 & $N / l^{*}$ \\
\hline Kanban & 30.3 & 16.7 & $\mathrm{~N} / \mathrm{I}^{*}$ \\
\hline Lead Time & $\mathrm{N} / \mathrm{I}^{*}$ & $\mathrm{~N} / \mathrm{I}^{*}$ & $\mathrm{~N} / \mathrm{I}^{*}$ \\
\hline $\begin{array}{l}\text { Long-term supplier and customer } \\
\text { relationship }\end{array}$ & 13.5 & 0.1 & $\mathrm{~N} / \mathrm{I}^{*}$ \\
\hline Multifunctional workforce & 11.2 & 6.7 & 10.9 \\
\hline Plant layout & 16.3 & 0.0 & $\mathrm{~N} / \mathrm{I}^{*}$ \\
\hline Poka Yoke & $\mathrm{N} / \mathrm{I}^{*}$ & 4.8 & $\mathrm{~N} / \mathrm{I}^{*}$ \\
\hline Production smoothing/Heijunka & $\mathrm{N} / \mathrm{I}^{*}$ & 7.2 & 10.9 \\
\hline Pull production & 22.5 & $\mathrm{~N} / \mathrm{I}^{*}$ & 13.9 \\
\hline $\begin{array}{l}\text { Single Minute Exchange of Die } \\
\text { (SMED) }\end{array}$ & 23.6 & 6.7 & 12.9 \\
\hline Simulation & $\mathrm{N} / \mathrm{I}^{*}$ & 3.3 & $\mathrm{~N} / \mathrm{I}^{*}$ \\
\hline Small lot size & 16.3 & $\mathrm{~N} / \mathrm{I}^{*}$ & 7.9 \\
\hline Standardized Work & 19.1 & 3.3 & 7.9 \\
\hline Supply Chain Integration & 16.9 & $\mathrm{~N} / \mathrm{I}^{*}$ & 5.0 \\
\hline Takt time & 14.6 & $\mathrm{~N} / \mathrm{I}^{*}$ & 13.9 \\
\hline Top management commitment & 14.0 & $N / l^{*}$ & $\mathrm{~N} / \mathrm{I}^{*}$ \\
\hline Total productive maintenance & 15.7 & 10.5 & 12.9 \\
\hline Total quality management & 18.5 & 8.6 & 4.0 \\
\hline Uniform work load & 15.2 & $N / I^{*}$ & $\mathrm{~N} / \mathrm{I}^{*}$ \\
\hline Value stream mapping & 28.7 & 24.9 & 5.9 \\
\hline Visual Management & 15.2 & 5.7 & 7.9 \\
\hline
\end{tabular}

$\mathrm{N} / \mathrm{I}^{*}$ - Not identified by the authors; Source: Prepared by the authors.

Based on the preparation of Table 2, it is possible to identify a set of 31 techniques and tools that can help the successful implementation of Lean Production Systems in the organizational environment. It is worth mentioning that none of these techniques and tools presents itself as higher level of use by the three compared studies. 
The techniques and tools of Value Stream Mapping, Kanban and Kaizen stand out with a high level of utilization in studies from Vamsi Krishna Jasti \& Kodali (2014) and Bhamu \& Sangwan (2014), while Pull production and Single Minute Exchange of Die are highlighted in studies from Vamsi Krishna Jasti \& Kodali (2014) and Marodin \& Saurin (2013).

From the study of Bhamu \& Sangwan (2014), Pull production, Just-in-Time and 5S also stand out, while in the study from Marodin \& Saurin (2013), Cellular manufacturing/GT, Multifunctional workforce, Total Productive Maintenance and Takt Time are highlighted. Such techniques and tools, as classification of Feld (2001), are mostly associated with improvements on manufacturing flow, process control and logistics.

In the agribusiness sector, in particular, the identified publications that depict the application of Lean Production System present, predominantly, exploratory and descriptive character. From these, the case study is the research method for (Barth et al., 2013; Cox et al., 2007; Perez et al., 2010; Silva, 2006; Simons \& Zokaei, 2005; Taylor, 2006; Simons \& Taylor, 2007; Tanco et al., 2013; Xie \& Li, 2012) and the survey method for (Cardozo et al., 2011; Claire et al., 2014; Forrester et al., 2010; Tomazela et al., 2010).

The emphasis as the approach to data analysis is mostly qualitative (80\%), except to the study of Xie \& Li (2012) with quantitative approach and Simons \& Taylor (2007) and Tomazela et al. (2010) of mixed approach.

Regarding the application segment of studies in agribusiness, these are concentrated mostly (66\%) in the livestock sector (Claire et al., 2014; Cox et al., 2007; Dora \& Gellynck, 2015; Perez et al., 2010; Simons \& Zokaei, 2005; Simons \& Taylor, 2007; Taylor, 2005, 2006; Silva, 2006; Xie \& Li, 2012), with specific studies on sugarcane industry (Tomazela et al., 2010); equipment for laying poultry (Barth et al., 2013), food products (Tanco et al., 2013) and fishing (Talip et al., 2011).

Taking into account the approach aligned to designated research methods, studies aim at the implementation of the Lean Production System in parts of the process (Xie \& Li, 2012), in the organization (Barth et al, 2013; Dora \& Gellynck, 2015; Tanco et al., 2013), and in the supply chain (Cox et al., 2007; Perez et al., 2010; Simons \& Taylor, 2007; Simons \& Zokaei, 2005; Taylor, 2005, 2006). Evaluation studies also occur on the use of Lean Production System in internal environments of the organization or along the chain (Claire et al., 2014; Dora et al., 2013; Forrester et al., 2010; Cardozo et al., 2011; Silva, 2006; Tomazela et al., 2010).

The application of techniques and tools is the basis for the conduction of studies as a subsidy to boost the implementation, or as a means of evaluation. The map of the techniques and tools used in the studies are presented in Table 3. 
Table 3. Techniques and tools that address Lean Production System to agribusiness.

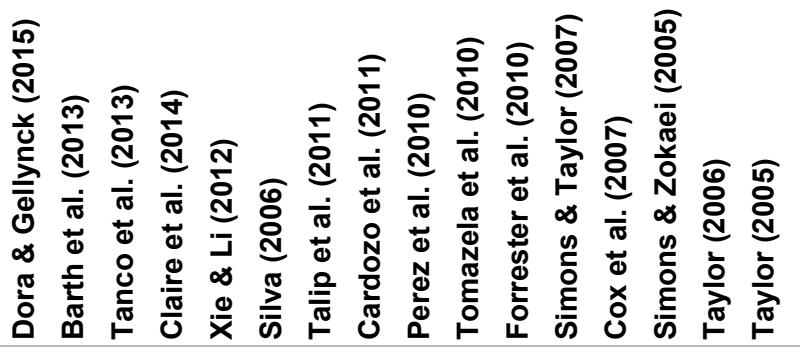

$5 S$

$\mathrm{x} \times$

Automation/Jidoka

x $\quad 6.3$

Celular Manufacturing/GT

$x \quad x \quad x$ 18.8

Concurement Engennering

Continuous flow

$x \quad x \quad x$

Customer involvement

$\mathrm{X}$

Employee commitment

Flexible information system

Just in time production

Just in time purchasing

Kaizen

Kanban

Lead Time

Long-term supplier and

customer relationship

$x$

x $x$

$\begin{array}{lll}\mathrm{x} & \mathrm{x} & 18.8 \\ \mathrm{x} & \mathrm{x} & 12.5\end{array}$

$\begin{array}{lll}x & x & 12.5\end{array}$

Multifunctional employees

Overall equipment effectiveness $\mathrm{x} x$ $\mathrm{X}$ $\mathrm{x}$ 31.3

$\begin{array}{lll}x & x & 18.8 \\ x & x & 18.8\end{array}$

$\mathrm{x}$

$\mathrm{x}$ 18.8

$\mathrm{x}$

$\mathrm{x} \quad \mathrm{x}$

$x \quad x$

37.5

Plant layout

$x$ 0.0

Poka-Yoke

$\mathrm{X}$

Production smoothing/Heijunka $x$

Pull

$\mathrm{x}-\mathrm{x}$

$\mathrm{X}$

$\mathrm{X}$

Set up time reduction

$\mathrm{X}$

Simulation

Small lot size

Standardization of work

Supplier involvement

Takt time

Top management commitment

Total productive maintenance

Total quality management

Uniform work load

Value stream mapping

Visual factory

Source: Prepared by the authors. 
For the collected studies, the use of techniques and tools is, more often, attached to the identification and coordination of manufacturing flow, so it can be cited Value Stream Mapping (50\%), Production smoothing/Heijunka (43.8\%); Total Quality Management (31.8\%), Kaizen (31.8\%) and Continuous flow (37.5\%). The establishment of partnerships through long-term supplier and customer relationship (37.5\%) can also be observed in the studies.

This set of techniques and tools that stand out in these papers are associated with the Feld classification (2001) categories of manufacturing flow and logistics. When compared to Table 1, only three techniques and tools coincide as the most cited in the papers, they are: Value Stream Mapping, Kaizen and Continuous flow. This diversity on the use of techniques and tools can be a characteristic to meet the productive specificities of the agribusiness environment, which confirms the sight of Karim \& Arif-Uz-Zaman (2013), in which the techniques and tools to be adopted by a organization should consider the environment to which they are inserted.

\section{Methodological procedures}

The methodological basis used in this study is an applied research. The research, as its objective, has descriptive character by looking for the identification of the existence of relationships between variables, seeking to determine the nature of this relationship (Kumar, 2014) in order to understand the importance of a phenomenon and provide subsidies for the construction of these theories or the refinement of them.

This situation applies to this research proposal because the study aims to identify which techniques and tools related to Lean Production System are applied in agribusiness, and, according to the theory proposed by Voss et al. (2002), with the focus on how the phenomenon happens or how it is structured and works on a system, method, process or operational reality.

Regarding the approach or style, this study shows the qualitative profile by presenting, second Cassell \& Symon (2004), a focus on interpretation rather than quantification and guidance to the process rather than to the result. It also presents a preoccupation with the context, in the sense that people's behavior and condition are closely linked in the formation of experience. Thus, for the recognition of the impact of the research process on the research situation it is assumed that the researcher influences the research situation and it is for it also influenced.

The type of research has support for the concept of case study. This study aims to examine contemporary events in a real and recent context, in which relevant behaviors can not be manipulated and so far have not been clearly defined in literature. Furthermore, there are more variables of interest to be investigated than data to be collected, thus characterizing as a case study (Voss et al., 2002).

Therefore, the case study as a research proposition indicates a recent phenomenon within a real life context, especially when the boundaries between phenomenon and context are not clearly defined. So, the research is technically an unique situation, since there will be many more variables of interest than data points and, as a result, this ends up being based on multiple evidence sources and also benefiting from the prior development of theoretical propositions to guide the collection and analysis of data (Yin, 2013).

As opposed to what was thought, the case study does not need to contain a full explanation, since its purpose is to establish a structure of argument and discussions (Yin, 2013). 
Considering the purpose of the research, this study has the characteristic of a case study as a theory construction, although the phenomenon under study, called Lean Production System is already developed. There is the need to identify and describe the key variables, highlighting the links and the reasons for the relationship between the studied variables (Voss et al., 2002). To accomplish this, the research proposal is based on tools for data collection, document viewing and observation, means in order to perform the triangulation, i.e., the use and combination of different methods to study the same phenomena, as well as to avoid sharing the same weaknesses (Voss et al., 2002).

The selection and conduction of multiple case studies were based on the identification of active agribusiness organizations in different segments. This was done in order to meet an initial profile of exploration and description of how the techniques and tools of Lean Production System are being used in these agribusiness environments.

For this purpose, the region of Alta Paulista was selected. Located in the state of São Paulo (Brazil), this region has centralized economy based on agriculture and livestock.

In order to collect data, those responsible for production management were identified through previous contacts in the Research Units. Thus, the research began by applying the data collection instrument that, in this research, is a form elaborated based on the theoretical background of studies carried out by Feld (2001), Liker (2003), Vamsi Krishna Jasti \& Kodali (2014), Bhamu \& Sangwan (2014) and Marodin \& Saurin (2013).

Split into two stages, the form in its first stage aims to identify the characterization of the Research Unit as the segment, company size and governance structure. In the second stage, enters into productive topics, focusing on Lean Production techniques and tools used in the internal environment of organizations.

At the conclusion of applying the form, visits were conducted at the production environments, which allowed to confirm the points highlighted during the interview and to evidence the Lean practices conducted through observation of documents within the manufacturing area.

This data collection phase took place from June to November 2015 with the visit of the Research Units lasted, on average, one hour and fourty five minutes.

\section{Research results}

As mentioned above, eight Research Units were selected from different segments and industrial size, highlighted in Table 4. The choice of Research Units occurred by emphasis in their field of expertise, either at national or state level.

Table 4. Characterization of the Research Units participating in the case studies.

\begin{tabular}{cccccc}
\hline \multirow{2}{*}{$\begin{array}{c}\text { Research } \\
\text { Unit }\end{array}$} & $\begin{array}{c}\text { Agribusiness } \\
\text { segment }\end{array}$ & $\begin{array}{c}\text { Number of } \\
\text { employees }\end{array}$ & $\begin{array}{c}\text { Industrial } \\
\text { size }\end{array}$ & $\begin{array}{c}\text { Governance } \\
\text { structure }\end{array}$ & $\begin{array}{c}\text { Job title of } \\
\text { the } \\
\text { interviewee }\end{array}$ \\
\hline A & $\begin{array}{c}\text { Poultry } \\
\text { farming }\end{array}$ & $20-99$ & Small & Family-run & $\begin{array}{c}\text { Industrial } \\
\text { manager }\end{array}$ \\
\hline
\end{tabular}




\begin{tabular}{|c|c|c|c|c|c|}
\hline \multirow[b]{2}{*}{$\begin{array}{l}\text { Research } \\
\text { Unit }\end{array}$} & \multicolumn{5}{|c|}{ Characteristics } \\
\hline & $\begin{array}{l}\text { Agribusiness } \\
\text { segment }\end{array}$ & $\begin{array}{l}\text { Number of } \\
\text { employees }\end{array}$ & $\begin{array}{l}\text { Industrial } \\
\text { size }\end{array}$ & $\begin{array}{l}\text { Governance } \\
\text { structure }\end{array}$ & $\begin{array}{c}\text { Job title of } \\
\text { the } \\
\text { interviewee }\end{array}$ \\
\hline B & $\begin{array}{c}\text { Poultry } \\
\text { farming } \\
\text { equipaments }\end{array}$ & $100-500$ & Midsize & Family-run & $\begin{array}{l}\text { Industrial } \\
\text { manager }\end{array}$ \\
\hline C & $\begin{array}{l}\text { Agricultural } \\
\text { machines }\end{array}$ & $>500$ & Large & Family-run & $\begin{array}{l}\text { Industrial } \\
\text { Engineer }\end{array}$ \\
\hline $\mathrm{D}$ & Alimentary & $100-500$ & Midsize & Family-run & $\begin{array}{l}\text { Production } \\
\text { Coordinators }\end{array}$ \\
\hline$E$ & $\begin{array}{c}\text { Rubber } \\
\text { processing }\end{array}$ & $20-99$ & Small & $\begin{array}{l}\text { Cooperative } \\
\text { management }\end{array}$ & $\begin{array}{c}\text { Department } \\
\text { manager }\end{array}$ \\
\hline $\mathrm{F}$ & Pig farming & $20-99$ & Small & Family-run & $\begin{array}{l}\text { General } \\
\text { Director }\end{array}$ \\
\hline G & $\begin{array}{l}\text { Sugarcane } \\
\text { industry }\end{array}$ & $>500$ & Large & $\begin{array}{l}\text { Professional } \\
\text { management }\end{array}$ & $\begin{array}{l}\text { Production } \\
\text { Coordinator }\end{array}$ \\
\hline $\mathrm{H}$ & $\begin{array}{l}\text { Natural silk } \\
\text { spinning }\end{array}$ & $100-500$ & Midsize & $\begin{array}{l}\text { Professional } \\
\text { management }\end{array}$ & $\begin{array}{c}\text { Production, } \\
\text { maintenance } \\
\text { and financial } \\
\text { managers }\end{array}$ \\
\hline
\end{tabular}

It is identified in Table 4 that the profile of research units differs from each other. Regarding the size of the company, depending on the number of employees, three companies are classified as small and mid-sized and two are classified as large size. With respect to governance structure, five research units feature as Family-run, two with a professional management and one shows the cooperative management profile.

Table 5 shows the present scenario of the Lean Production System for the Research Units. It is noted that only one has the Lean Production System completely formalized, while three others have strong Lean initiatives already formalized and disclosed in its organizational environment and four do not perform training actions related to Lean Production System.

Table 5. Characteristics on the level of formalization of Lean Production on Research Units.

\begin{tabular}{ccccc}
\hline $\begin{array}{c}\text { Research } \\
\text { Units }\end{array}$ & $\begin{array}{c}\text { Formalized Lean } \\
\text { Production } \\
\text { System }\end{array}$ & $\begin{array}{c}\text { Responsible } \\
\text { assigned to } \\
\text { Lean } \\
\text { management }\end{array}$ & $\begin{array}{c}\text { Adoption of } \\
\text { Lean } \\
\text { practices and } \\
\text { tools }\end{array}$ & $\begin{array}{c}\text { Classification } \\
\text { regarding the } \\
\text { production } \\
\text { environment * }\end{array}$ \\
\hline A & No & No & Yes & MTS \\
\hline B & Partially & Yes & Yes & MTO \\
\hline C & Yes & Yes & Yes & MTO \\
\hline D & No & No & Yes & MTS \\
\hline E & No & No & Yes & MTS \\
\hline F & No & No & Yes & MTS \\
\hline G & Partially & Yes & Yes & MTO \\
\hline H & Partially & No & Yes & MTO
\end{tabular}

${ }^{*}$ Classification from definitions of Wikner \& Rudberg (2005) - MTO - Make to Order; MTS - Make to Stock; Source: Prepared by the authors. 
Regarding designation of those responsible for Lean Production System management in the organizational environment, only three units highlighted having a person responsible for its management.

The Research Units have the production environment classified equitably with the Make to Stock (MTS) and Make to Order (MTO) profile. At this point it should be clarified that although mainly the production of Research Units B and C are MTO, they also perform customized projects, which are characteristic of the production environment Engineer to Order (ETO). This can be explained from the point of view of Wikner \& Rudberg (2005) which indicate the ETO as a special case of MTO.

Regarding the Research Units with MTO production feature all of them use the pull production as a demand management mechanism. Such fact is facilitated by the characteristic of supply contracts which are previously established, allowing production to be directed towards the accurate meeting demand.

The use of techniques and tools associated with Lean philosophy was pointed out by all organizations as can be seen at column 4 of Table 5 . However, the adoption of Lean Production System is not formalized for all Research Units, as seen at column 2 of Table 5.

For each of the Research Units, Table 6 highlights the use of Lean Production techniques and tools according to the interviewees, as well as observed during on site visits.

Table 6. Techniques and Tools of Lean Production System employed by the research units and its utilization percentage.

\begin{tabular}{|c|c|c|c|c|c|c|c|c|c|}
\hline \multirow{2}{*}{ Techniques and Tools } & \multicolumn{8}{|c|}{ Research Unit } & \multirow{2}{*}{$\%$} \\
\hline & A & B & C & D & $\mathbf{E}$ & $\mathbf{F}$ & G & $\mathbf{H}$ & \\
\hline $5 S$ & & & $x$ & & & & $x$ & $x$ & 37.5 \\
\hline Autonomation/Jidoka & $x$ & $x$ & $x$ & $x$ & $x$ & & $x$ & $x$ & 87.5 \\
\hline Cellular manufacturing/(GT) & & & $x$ & & & & $x$ & & 25.0 \\
\hline Concurrent engineering & & & $x$ & & & & $x$ & & 25.0 \\
\hline Continuous flow & $x$ & & $x$ & $x$ & $x$ & $x$ & $x$ & $x$ & 87.5 \\
\hline Customer involvement & & & & & & & & & 0.0 \\
\hline Employee commitment & & & & & & & & & 0.0 \\
\hline Flexible information system & & & & & & & & & 0.0 \\
\hline Just in time production & & & & & & & & & 0.0 \\
\hline Just in time purchasing & & & $x$ & & & & $x$ & & 25.0 \\
\hline Kaizen & & & $x$ & $x$ & $x$ & & $x$ & $x$ & 62.5 \\
\hline Kanban & & & $x$ & $x$ & & $x$ & & $x$ & 50.0 \\
\hline Lead Time & & & $x$ & & & & & & 12.5 \\
\hline $\begin{array}{l}\text { Long-term supplier and } \\
\text { customer relationship }\end{array}$ & & & & & & & & & 0.0 \\
\hline Multifunctional workforce & $x$ & & $x$ & & & & $x$ & & 37.5 \\
\hline Plant layout & & & & & & & & & 0.0 \\
\hline Poka-Yoke & $x$ & $x$ & $x$ & $x$ & & & & $x$ & 62.5 \\
\hline Production smoothing/Heijunka & & & & & & & & & 0.0 \\
\hline Pull production & $x$ & $x$ & $x$ & $x$ & $x$ & & $x$ & $x$ & 87.5 \\
\hline $\begin{array}{l}\text { Single Minute Exchange of Die } \\
\text { (SMED) }\end{array}$ & & $x$ & $x$ & & & & & & 25.0 \\
\hline Simulation & & & & & & & & & 0.0 \\
\hline
\end{tabular}




\begin{tabular}{|c|c|c|c|c|c|c|c|c|c|}
\hline \multirow{2}{*}{ Techniques and Tools } & \multicolumn{8}{|c|}{ Research Unit } & \multirow{2}{*}{$\%$} \\
\hline & A & B & C & $\mathbf{D}$ & $\mathbf{E}$ & $\mathbf{F}$ & G & $\mathbf{H}$ & \\
\hline Small lot size & $x$ & $x$ & $x$ & & & & & & 37.5 \\
\hline Standardized Work & & $x$ & $x$ & $x$ & & & $x$ & $x$ & 62.5 \\
\hline Supply Chain Integration & $x$ & & $x$ & & $\mathrm{x}$ & $\mathrm{x}$ & $x$ & $x$ & 75.0 \\
\hline Takt time & & & $x$ & & & & $\mathrm{x}$ & $\mathrm{x}$ & 37.5 \\
\hline Top management commitment & & & & & & & & & 0.0 \\
\hline Total productive maintenance & & & $x$ & & & & $x$ & & 25.0 \\
\hline Total quality management & & & $x$ & & $x$ & $\mathrm{x}$ & $\mathrm{x}$ & $x$ & 62.5 \\
\hline Uniform work load & $x$ & & $x$ & $x$ & $x$ & $x$ & $x$ & $x$ & 87.5 \\
\hline Value stream mapping & & & $x$ & & & & & & 12.5 \\
\hline Visual Management & & $x$ & $x$ & & & & $x$ & & 37.5 \\
\hline
\end{tabular}

Source: Prepared by the authors.

Regarding Table 6, when considering the application of each of the techniques and tools, in general, it is noted that the most used are Autonomation/Jidoka, Continuous flow, Uniform work load and Pull production (87.5\%); Supply Chain Integration (75\%) and Total Quality Management, Kaizen, Poka Yoke and Standardized Work (62.5\%).

The techniques and tools that have the highest percentage of frequency on Research Units is consistent with the predisposition that companies seek to maintain and increase their production efficiency always focused on satisfying their customers and maximally reducing production costs. Supply Chain Integration means to decrease the number of suppliers and maintain long-term contracts, and this remains present because companies share a common characteristic, i.e., they adopt a flexible and participative management, so the culture to keep loyal to its suppliers is visible.

The use of techniques and tools of Lean Production System can be compared to theoretical studies presented in order to verify whether the uses of frequencies converge or not. Table 7 performs this comparison with respect to studies of Vamsi Krishna Jasti \& Kodali (2014), Bhamu \& Sangwan (2014) and Marodin \& Saurin (2013). In gray were highlighted five techniques and tools with highest percentage of use in each study and in light gray the five techniques and tools with lowest percentage of use indicated in each study.

Table 7. Comparison of use of techniques and tools: comparison between theory and case studies.

\begin{tabular}{|c|c|c|c|c|c|}
\hline \multirow[b]{2}{*}{ Tools and Techniques } & \multicolumn{5}{|c|}{ Frequency of use } \\
\hline & $\begin{array}{l}\text { Vamsi } \\
\text { Krishna } \\
\text { Jasti \& } \\
\text { Kodali } \\
\text { (2014) }\end{array}$ & $\begin{array}{c}\text { Bhamu } \\
\& \\
\text { Sangwa } \\
\text { n (2014) }\end{array}$ & $\begin{array}{c}\text { Marodin } \\
\text { \& Saurin } \\
(2013)\end{array}$ & $\begin{array}{l}\text { Studies } \\
\text { of Lean } \\
\text { Producti } \\
\text { on in } \\
\text { agribuss } \\
\text { iness }\end{array}$ & $\begin{array}{c}\text { Researc } \\
\text { h Units }\end{array}$ \\
\hline $5 S$ & 15.2 & 11.0 & 5.9 & 12.5 & 37.5 \\
\hline Automation/Jidoka & $\mathrm{N} / \mathrm{I}^{*}$ & 3.3 & 9.9 & 6.3 & 87.5 \\
\hline Celular Manufacturing/GT & $N / I^{*}$ & 9.6 & 10.9 & 18.8 & 25.0 \\
\hline Concurement Engennering & $\mathrm{N} / \mathrm{I}^{*}$ & $\mathrm{~N} / \mathrm{I}^{*}$ & 5.0 & $\mathrm{~N} / /^{*}$ & 25.0 \\
\hline Continuous flow & 15.2 & $N / /^{*}$ & 9.9 & 37.5 & 87.5 \\
\hline Customer involvement & 14.6 & $N / /^{*}$ & 5.0 & 6.3 & $N / I^{* *}$ \\
\hline
\end{tabular}




\begin{tabular}{|c|c|c|c|c|c|}
\hline \multirow[b]{2}{*}{ Tools and Techniques } & \multicolumn{5}{|c|}{ Frequency of use } \\
\hline & $\begin{array}{l}\text { Vamsi } \\
\text { Krishna } \\
\text { Jasti \& } \\
\text { Kodali } \\
\text { (2014) }\end{array}$ & $\begin{array}{c}\text { Bhamu } \\
\& \\
\text { Sangwa } \\
\text { n (2014) }\end{array}$ & $\begin{array}{c}\text { Marodin } \\
\text { \& Saurin } \\
(2013)\end{array}$ & $\begin{array}{l}\text { Studies } \\
\text { of Lean } \\
\text { Producti } \\
\text { on in } \\
\text { agribuss } \\
\text { iness }\end{array}$ & $\begin{array}{l}\text { Researc } \\
\text { h Units }\end{array}$ \\
\hline Employee commitment & 14.0 & $\mathrm{~N} / \mathrm{I}^{*}$ & $\mathrm{~N} / \mathrm{I}^{*}$ & $\mathrm{~N} / \mathrm{I}^{*}$ & $N / I^{* *}$ \\
\hline Flexible information system & 15.7 & $\mathrm{~N} / \mathrm{I}^{*}$ & $\mathrm{~N} / \mathrm{I}^{*}$ & 12.5 & $\mathrm{~N} / \mathrm{I}^{*}$ \\
\hline Just in time production & 16.3 & 16.3 & $\mathrm{~N} / \mathrm{I}^{*}$ & 18.8 & $\mathrm{~N} / \mathrm{I}^{*}$ \\
\hline Just in time purchasing & 19.1 & $N / I^{*}$ & 3.0 & 12.5 & 25.0 \\
\hline Kaizen & 28.1 & 16.3 & $N / I^{*}$ & 31.3 & 62.5 \\
\hline Kanban & 30.3 & 16.7 & $\mathrm{~N} / /^{*}$ & 18.8 & 50.0 \\
\hline Lead Time & $\mathrm{N} / \mathrm{I}^{*}$ & $\mathrm{~N} / \mathrm{I}^{*}$ & $\mathrm{~N} / \mathrm{I}^{*}$ & 18.8 & 12.5 \\
\hline $\begin{array}{l}\text { Long-term supplier and } \\
\text { customer relationship }\end{array}$ & 13.5 & 0.1 & $N / I^{*}$ & 37.5 & $N / I^{*}$ \\
\hline Multifunctional employees & 11.2 & 6.7 & 10.9 & $N / I^{*}$ & 37.5 \\
\hline Plant layout & 16.3 & $\mathrm{~N} / \mathrm{I}^{*}$ & $\mathrm{~N} / /^{*}$ & 6.3 & $\mathrm{~N} / \mathrm{I}^{*}$ \\
\hline Poka-Yoke & $\mathrm{N} / \mathrm{I}^{*}$ & 4.8 & $N / I^{*}$ & $N / I^{*}$ & 62.5 \\
\hline $\begin{array}{l}\text { Production } \\
\text { smoothing/Heijunka }\end{array}$ & $\mathrm{N} / \mathrm{I}^{*}$ & 7.2 & 10.9 & 43.8 & $N / I^{*}$ \\
\hline Pull & 22.5 & $\mathrm{~N} / \mathrm{I}^{*}$ & 13.9 & 25.0 & 87.5 \\
\hline Set up time reduction & 23.6 & 6.7 & 12.9 & 12.5 & 25.0 \\
\hline Simulation & $N / I^{*}$ & 3.3 & $\mathrm{~N} / \mathrm{I}^{*}$ & $\mathrm{~N} / \mathrm{I}^{*}$ & $\mathrm{~N} / \mathrm{I}^{*}$ \\
\hline Small lot size & 16.3 & $N / I^{*}$ & 7.9 & $\mathrm{~N} / \mathrm{I}^{*}$ & 37.5 \\
\hline Standardization of work & 19.1 & 3.3 & 7.9 & 25.0 & 62.5 \\
\hline Supplier involvement & 16.9 & $N / I^{*}$ & 5.0 & 31.3 & 75.0 \\
\hline Takt time & 14.6 & $\mathrm{~N} / \mathrm{I}^{*}$ & 13.9 & 12.5 & 37.5 \\
\hline $\begin{array}{l}\text { Top management } \\
\text { commitment }\end{array}$ & 14.0 & $N / I^{*}$ & $\mathrm{~N} / \mathrm{I}^{*}$ & $N / I^{*}$ & $N / I^{*}$ \\
\hline $\begin{array}{l}\text { Total productive } \\
\text { maintenance }\end{array}$ & 15.7 & 10.5 & 12.9 & 12.5 & 25.0 \\
\hline Total quality management & 18.5 & 8.6 & 4.0 & 31.3 & 62.5 \\
\hline Uniform work load & 15.2 & $\mathrm{~N} / \mathrm{I}^{*}$ & $\mathrm{~N} / \mathrm{I}^{*}$ & 18.8 & 87.5 \\
\hline Value stream mapping & 28.7 & 24.9 & 5.9 & 50.0 & 12.5 \\
\hline Visual factory & 15.2 & 5.7 & 7.9 & 6.3 & 37.5 \\
\hline
\end{tabular}

$\mathrm{N} / \mathrm{I}^{*}$ - Not identified by the authors; Source: Prepared by the authors.

A Table 7 analysis reveals some important aspects regarding the use of techniques and tools for agribusiness environments:

- In general, the techniques and tools identified with higher use frequency by Vamsi Krishna Jasti \& Kodali (2014), Bhamu \& Sangwan (2014), and Marodin \& Saurin (2013) do not appear similar when compared with the case studies conducted;

- However, there is similarity in four techniques and tools when compared to studies that focus on agribusiness environment: Continuous flow, Supplier involvement, Kaizen and Total Quality Management. Such fact can be an indication about the convergence of techniques and tools of Lean Production System which may be employed with a higher degree of success within the agribusiness environments; 
- Only two techniques and tools (Kaizen and Pull Production) present high incidence in two theoretical studies, in addition to the indication by the agribusiness units. Such fact can be explained by the characteristics inherent in the adoption of Lean practices, since the Kaizen seeks to generate a culture in the organization by the constant pursuit of perfection and, Pull production reflects the need to know the products and quantities to be produced, triggering the process only when necessary. Such fact for an agribusiness environment becomes more important because of the high perishability of the product, which is characteristic of this production system (Gunderson et al., 2014);

- Supply Chain Integration also appears as one of the tools with a strong focus for the Research Units. Such fact occurs because important factors in the management of an agribusiness chain as the perishability of the raw material, edaphoclimatic factors and biological conditions strongly influence the quality of the product to be generated, bringing the need for closer proximity between Research Unit and supplier (Barnard et al., 2016; Gunderson et al., 2014; Perez et al., 2010);

- The techniques and tools Autonomation/Jidoka, Continuous flow, Total Quality Management and Uniform work load are highlighted due to the high rate of use in the studied Research Units. But they don't appear with a high rate of use in comparative studies. Some techniques and tools indicated with a high rate of use by agribusiness units, such as Poka Yoke, Standardized work and Supply Chain Integration stand out in comparative studies with low rate of use;

- The opposite occurs with the Single Minute Exchange of Die technique in studies of Vamsi Krishna Jasti \& Kodali (2014) and Marodin \& Saurin (2013), which appears as one of the most used, however, for agrobusiness units is at a low rate of use. Such fact can be explained by the continuous production characteristic in the agribusiness environments, which require a smaller number of stops for the preparation of machinery. However, a point of further analysis should be verification why this technique is not used in conjunction with Just in time which, according to Barnard et al. (2016), brings a wider range of benefits to the organization;

- Finally, it is noted that the techniques and tools known as long-term supplier, customer relationship, production smoothing/Heijunka and Value Stream Mapping stood out with a high use frequency in theoretical studies of Lean Production did not show the same frequency in applied researches for agribusiness. Such fact can be given by the characteristic of the studies conducted so far in literature, which seek to evaluate the production chain and to perform a management process in a most effective way.

Another analysis of the bibliographic research can be conducted through the establishment of relations between five categories indicated in the classification by Feld (2001) - Manufacturing flow, Organization, Process control, Metrics and Logistics - and the techniques and tools applied in the implementation of Lean Production System in agribusiness segment identified in Table 8. 
Table 8. Relations of techniques and tools from conducted research against Feld classification (2001)

\begin{tabular}{|c|c|c|c|c|c|c|c|c|c|c|}
\hline \multirow{2}{*}{ Categories } & \multirow{2}{*}{ Techniques and Tools } & \multicolumn{8}{|c|}{ Research Unit } & \multirow{2}{*}{$\%$} \\
\hline & & A & $\mathbf{B}$ & C & D & $\mathbf{E}$ & $\mathbf{F}$ & G & $\mathbf{H}$ & \\
\hline \multirow[t]{6}{*}{ Logistics } & Continuous flow & $x$ & & $x$ & $x$ & $x$ & $x$ & $x$ & $x$ & 87.5 \\
\hline & Just in time purchasing & & & $x$ & & & & $x$ & & 25.0 \\
\hline & Pull production & $x$ & $x$ & $x$ & $x$ & $x$ & & $x$ & $x$ & 87.5 \\
\hline & Simulation & & & & & & & & & $\mathrm{N} / /^{*}$ \\
\hline & Small lot size & $x$ & $x$ & $x$ & & & & & & 37.5 \\
\hline & Supply Chain Integration & $x$ & & $x$ & & $x$ & $x$ & $x$ & $x$ & 75.0 \\
\hline \multirow{9}{*}{$\begin{array}{l}\text { Manufacturin } \\
\mathrm{g} \text { flow }\end{array}$} & Cellular Manufacturing/GT & & & $x$ & & & & $x$ & & 25.0 \\
\hline & Just in time production & & & & & & & & & $\mathrm{N} / /^{*}$ \\
\hline & Kanban & & & $x$ & $x$ & & $x$ & & $x$ & 50.0 \\
\hline & Plant layout & & & & & & & & & $\mathrm{N} / /^{*}$ \\
\hline & $\begin{array}{l}\text { Production smoothing/ } \\
\text { Heijunka }\end{array}$ & & & & & & & & & $\mathrm{N} / \mathrm{I}^{*}$ \\
\hline & Standardized Work & & $x$ & $x$ & $x$ & & & $x$ & $x$ & 62.5 \\
\hline & Takt time & & & $x$ & & & & $x$ & $x$ & 37.5 \\
\hline & Uniform work load & $x$ & & $x$ & $x$ & $x$ & $x$ & $x$ & $x$ & 87.5 \\
\hline & Value stream mapping & & & $x$ & & & & & & 12.5 \\
\hline Metrics & Lead Time & & & $x$ & & & & & & 12.5 \\
\hline \multirow[t]{6}{*}{ Organization } & Customer involvement & & & & & & & & & $\mathrm{N} / /^{*}$ \\
\hline & Employee commitment & & & & & & & & & $\mathrm{N} / \mathrm{I}^{*}$ \\
\hline & $\begin{array}{l}\text { Flexible information } \\
\text { system }\end{array}$ & & & & & & & & & $\mathrm{N} / \mathrm{I}^{*}$ \\
\hline & $\begin{array}{l}\text { Long-term supplier and } \\
\text { customer relationship }\end{array}$ & & & & & & & & & $N / I^{*}$ \\
\hline & Multifunctional workforce & $x$ & & $x$ & & & & $x$ & & 37.5 \\
\hline & $\begin{array}{l}\text { Top management } \\
\text { commitment }\end{array}$ & & & & & & & & & $\mathrm{N} / \mathrm{I}^{*}$ \\
\hline \multirow{9}{*}{$\begin{array}{l}\text { Process } \\
\text { control }\end{array}$} & $5 S$ & & & $x$ & & & & $x$ & $x$ & 37.5 \\
\hline & Autonomation/Jidoka & $x$ & $x$ & $x$ & $x$ & $x$ & & $x$ & $x$ & 87.5 \\
\hline & Concurrent engineering & & & $x$ & & & & $x$ & & 25.0 \\
\hline & Kaizen & & & $x$ & $x$ & $x$ & & $x$ & $x$ & 62.5 \\
\hline & Poka-Yoke & $x$ & $x$ & $x$ & $x$ & & & & $x$ & 62.5 \\
\hline & $\begin{array}{l}\text { Single Minute Exchange of } \\
\text { Die (SMED) }\end{array}$ & & $\mathrm{x}$ & $x$ & & & & & & 25.0 \\
\hline & $\begin{array}{l}\text { Total productive } \\
\text { maintenance }\end{array}$ & & & $x$ & & & & $x$ & & 25.0 \\
\hline & Total quality management & & & $x$ & & $x$ & $x$ & $x$ & $\mathrm{x}$ & 62.5 \\
\hline & Visual Management & & $x$ & $x$ & & & & $x$ & & 37.5 \\
\hline
\end{tabular}

$\mathrm{N} / \mathrm{I}^{*}-$ Not identified by the authors; Source: Prepared by the authors.

The classification about the use of techniques and tools, according to Feld (2001), identifies important aspects concerning the use of techniques and tools of Lean Production System for agribusiness units investigated.

It is noted that the Process Control category concentrates four of the most commonly used techniques and tools for the investigated units. Such aspect can be 
explained by the need for monitoring, control, stabilization and improvement of the production process because, in general, many agribusiness sectors deal with highly perishable products and require constant monitoring to guarantee its quality.

The Logistics category presents other three techniques and tools most frequently used by Research Units (Supply Chain Integration, Pull production, Continuous flow) and that are essential to establish operational rules and control internal and external material flows.

In Manufacturing flow category, techniques and tools deserving attention are Standardized work and Uniform work load, which help define standards of production and work closely to the techniques and tools that were highlighted in Logistics category.

It is also noted that there is a low use of techniques and tools concerning the Organization and Metrics categories. It is noteworthy in this diagnosis that the studies identified in the agribusiness sector guide the implementation of Lean Production System in the productive performance of the organization, aiming mostly results and gains in productive sector.

Looking at data of the Research Units from the perspective of the production environment (MTO or MTS), depicted in Table 9, identifies that eight techniques and tools are presented with greater emphasis in MTO production environment, with a relative usage percentage equal or higher than $50 \%$ when analyzed their use in MTS environment.

Table 9. Percentage of use of techniques and tools according to the type of production environment.

\begin{tabular}{|c|c|c|c|c|c|c|c|c|c|c|}
\hline \multirow{4}{*}{ Tools and Techniques } & \multicolumn{10}{|c|}{ Production Environment } \\
\hline & \multicolumn{5}{|c|}{ Make to Stock - MTS } & \multicolumn{5}{|c|}{ Make to Order - MTO } \\
\hline & \multicolumn{4}{|c|}{ Research Unit } & \multirow{2}{*}{$\%$} & \multicolumn{4}{|c|}{ Research Unit } & \multirow{2}{*}{$\%$} \\
\hline & A & D & $\mathbf{E}$ & $\mathbf{F}$ & & B & C & G & $\mathbf{H}$ & \\
\hline $5 S$ & & & & & 0 & & $x$ & $x$ & $x$ & 75 \\
\hline Automation/Jidoka & $x$ & $\mathrm{x}$ & $x$ & & 75 & $x$ & $x$ & $x$ & $x$ & $\begin{array}{c}10 \\
0\end{array}$ \\
\hline Celular Manufacturing/GT & & & & & 0 & & $x$ & $x$ & & 50 \\
\hline Concurement Engennering & & & & & 0 & & $x$ & $x$ & & 50 \\
\hline Continuous flow & $x$ & $\mathrm{X}$ & $x$ & $\mathrm{x}$ & 100 & & $x$ & $x$ & $x$ & 75 \\
\hline Customer involvement & & & & & 0 & & & & & 0 \\
\hline Employee commitment & & & & & 0 & & & & & 0 \\
\hline Flexible information system & & & & & 0 & & & & & 0 \\
\hline Just in time production & & & & & 0 & & & & & 0 \\
\hline Just in time purchasing & & & & & 0 & & $x$ & $x$ & & 50 \\
\hline Kaizen & & $x$ & $\mathrm{x}$ & & 50 & & $x$ & $x$ & $x$ & 75 \\
\hline Kanban & & $x$ & & $x$ & 50 & & $x$ & & $x$ & 50 \\
\hline Lead Time & & & & & 0 & & $x$ & & & 25 \\
\hline $\begin{array}{l}\text { Long-term supplier and } \\
\text { customer relationship }\end{array}$ & & & & & 0 & & & & & 0 \\
\hline Multifunctional employees & $x$ & & & & 25 & & $x$ & $x$ & & 50 \\
\hline Plant layout & & & & & 0 & & & & & 0 \\
\hline Poka-Yoke & $x$ & $x$ & & & 50 & $x$ & $x$ & & $x$ & 75 \\
\hline Production smoothing/Heijunka & & & & & 0 & & & & & 0 \\
\hline
\end{tabular}




\begin{tabular}{|c|c|c|c|c|c|c|c|c|c|c|}
\hline \multirow{4}{*}{ Tools and Techniques } & \multicolumn{10}{|c|}{ Production Environment } \\
\hline & \multicolumn{5}{|c|}{ Make to Stock - MTS } & \multicolumn{5}{|c|}{ Make to Order - MTO } \\
\hline & \multicolumn{4}{|c|}{ Research Unit } & \multirow{2}{*}{$\%$} & \multicolumn{4}{|c|}{ Research Unit } & \multirow{2}{*}{$\%$} \\
\hline & A & D & $\mathbf{E}$ & $\mathbf{F}$ & & B & C & G & $\mathbf{H}$ & \\
\hline Pull & $x$ & $x$ & $x$ & & 75 & $x$ & $x$ & $x$ & $x$ & $\begin{array}{c}10 \\
0\end{array}$ \\
\hline Set up time reduction & & & & & 0 & $x$ & $x$ & & & 50 \\
\hline Simulation & & & & & 0 & & & & & 0 \\
\hline Small lot size & $x$ & & & & 25 & $x$ & $x$ & & & 50 \\
\hline Standardization of work & & $x$ & & & 25 & $x$ & $x$ & $x$ & $x$ & $\begin{array}{c}10 \\
0\end{array}$ \\
\hline Supplier involvement & $x$ & & $x$ & $\mathrm{x}$ & 75 & & $x$ & $x$ & $\mathrm{x}$ & 75 \\
\hline Takt time & & & & & 0 & & $x$ & $x$ & $x$ & 75 \\
\hline Top management commitment & & & & & 0 & & & & & 0 \\
\hline Total productive maintenance & & & & & 0 & & $x$ & $x$ & & 50 \\
\hline Total quality management & & & $x$ & $x$ & 50 & & $x$ & $x$ & $x$ & 75 \\
\hline Uniform work load & $x$ & $x$ & $x$ & $x$ & 100 & & $x$ & $x$ & $x$ & 75 \\
\hline Value stream mapping & & & & & 0 & & $x$ & & & 25 \\
\hline Visual factory & & & & & 0 & $x$ & $x$ & $x$ & & 75 \\
\hline
\end{tabular}

Source: Prepared by the authors.

In this set are highlighted the techniques and tools that, according to Feld classification (2001), are associated with Process control and Manufacturing flow categories. In Process control category highlights are the techniques and tools: 5S, concurrement engennering, setup time reduction, Total Productive Maintenance and visual factory. In Manufacturing flow category highlights are Cellular manufacturing, just-in-time purchasing, standardization of work and takt time.

The greatest amount of techniques and tools when viewed from the point of view of MTO production can be explained by the fact that this type of production meets demand as customer request. From this point the calculation and release of manufacturing orders are made, with its own characteristic to meet each request (Zhang et al., 2013). Thus, it requires the use of various techniques and tools for managing the manufacturing flow and process control.

Finally, Figure 1 (constructed by the software Netdraw ${ }^{\circledR}$ ) shows the connection between the techniques and tools of Lean Production System according to the usage indications by the research units. The red circles correspond to the investigated agribusiness units, while the diamond shapes are related to the techniques and tools. As bigger is the symbol, largest are the usage indications. The colors correspond to category classification of Feld (2001) as described in the legend. The techniques and tools isolated in the network represent the absence of any indication by the agribusiness units. 


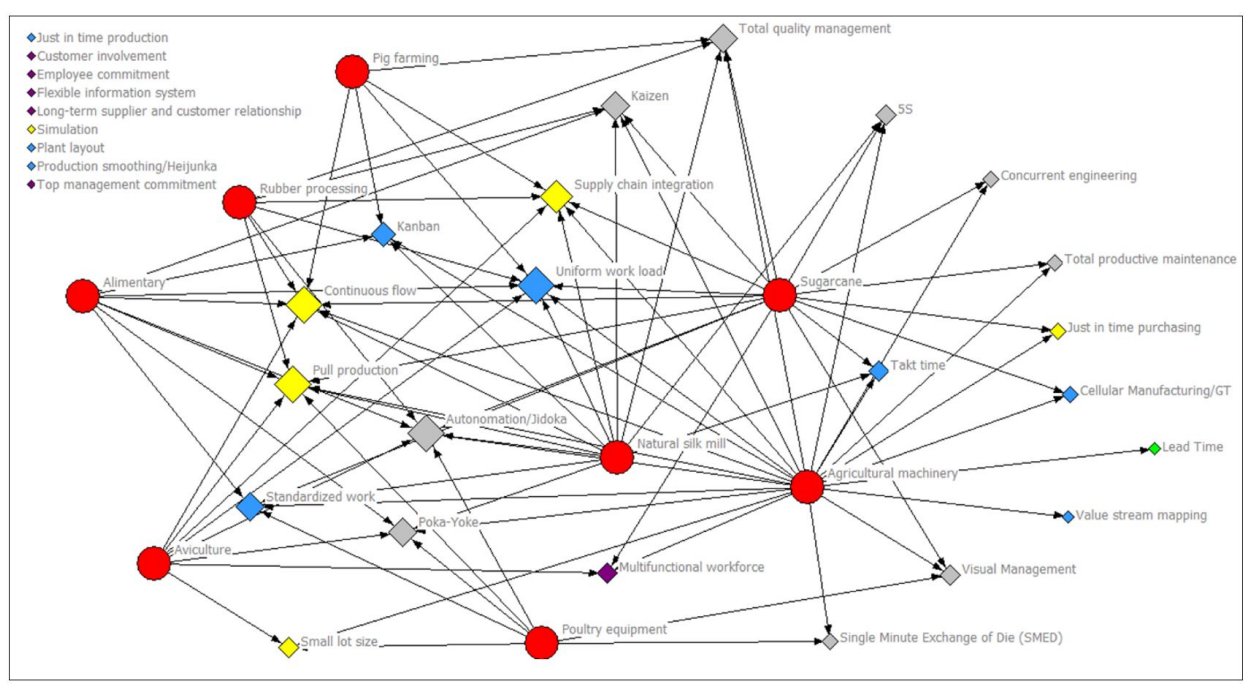

Figure 1. Social network interrelating the techniques and tools indicated by the agribusiness units. Source: Prepared by the authors.

The analysis of Figure 1 allows us to identify that the Research Units that operate in Sugarcane industry, Agricultural machines and Natural silk spinning play a fundamental role regarding the use of techniques and tools of Lean Production System, once they possess a larger indication of using them.

It also shows that the techniques and tools related to categories of Process control, Manufacturing flow and Logistics have a strong usage frequency. This is noted because they are centered on the network and feature a high degree of indication by the Research Units. It is noted finally that the techniques and tools related to Metrics and Organization categories possess only one network connection.

\section{Final considerations}

By conducting multiple case studies, associated with observation and analysis of documents, this research was successful in its proposal of identification which are the techniques and tools of Lean Production System that are being used in active organizations in the agribusiness environment and confront them with the existing literature.

Thus, the data collection was carried out in eight Research Units located in the state of São Paulo, Brazil. These Research Units are notable for its national and state importance in the field where they operate, and as well are differentiated about to the size and type of management.

The conduct of case studies to at eight Research Units identified an important set of information to a business sector little explored in the field of operations management, although of great importance for the world economy, the agribusiness sector.

The strategy for data collection proved to be suitable for the construction of the research and was carried out from the steps proposed by Yin (2013). A limitation of the method that is inherent in a case study is the impossibility of generalizing the data, which are true to the sample in question. However, allows glimpsing important propositions for future research. 
It is important to highlight some important findings of this study. First, it is noted by the literature review that techniques and tools can be used by agribusinesses, although they are still little explored by researchers. In these studies, in the agribusiness environment is identified that the most employed techniques and tools are Value Stream Mapping, Production smoothing/Heijunka, Total Quality Management, Kaizen, Continuous flow, Long-term supplier and Customer relationship.

When compared to studies that focus on the application of Lean Produciton in agribusiness environment, it is noted that there is similarity in three of most employed techniques and tool: Long-term supplier and Customer relationship, Production smoothing/ Heijunka and Value Stream Mapping. These techniques and tools are primarily associated with the need to know the supply chain and to establish its production in a balanced manner (Barnard et al., 2016), through the establishment of long-term relationships with suppliers, a fact that seeks to minimize the effects of seasonality of production and demand management (Perez et al., 2010).

However, it is noted that there is a higher tendency to use the techniques and tools related to the categories established by Feld (2001) that cover Process control, Manufacturing flow and Logistics. This tendency occurs with greater emphasis on Research Units working on a MTO production environment. Such aspects can be justified by the need for monitoring and control production processes of agribusiness items, which have specific characteristics for production compared to manufactured items (Barnard et al., 2016; Gunderson et al., 2014; Batalha \& Silva, 2008).

This study met its goal to contribute in the scientific field and the area of production management for the refinement of an already established theory, however little explored in the study object. For society, and for the agribusiness sector, this research makes clear answers about the feasibility of using the concepts and techniques and tools of Lean Production System, which can, when properly applied, bring productivity gains and competitiveness.

It also allows, from the identified data, mention gaps and future research that will help the most competitive management to this important segment of the world economy. Future research possibilities are: (i) research conduction of the survey type to investigate businesses in the agribusiness sector which will draw a profile on the use of techniques and tools of Lean Production System; (ii) establishment of a research with sector specialists and academics in order to interrelate how the various techniques and tools of Lean Production can help to overcome difficulties regarding the specificities of agribusiness and (iii) case studies in specific agribusiness sector in order to diagnose and to establish Lean management models that meet the organization's needs.

\section{Acknowledgements}

Research grants awarded by Support Foundation of São Paulo (FAPESP) and PROPe - Pro Rectory of Research - UNESP.

\section{References}

Barnard, F. L., Akridge, J. T., Dooley, F. J., Foltz, J. C., \& Yeager, E. A. (2016). Agribusiness management. United Kingdom: Routledge. http://dx.doi.org/10.4324/9781315709420.

Barth, A. P., Weise, A. D., \& Ruppenthal, J. E. (2013). Aplicação da manufatura enxuta em uma indústria de equipamentos agrícolas. Ingeniare. Revista Chilena de Ingeniería, 21(1), 147158. http://dx.doi.org/10.4067/S0718-33052013000100013. 
Batalha, M. O., \& Silva, A. L. (2008). Agroindustrial systems management: definitions, characteristics and methodological chains (in portuguese). In M. O. Batalha. Gestão agroindustrial (pp. 1-62). São Paulo: Atlas.

Belekoukias, I., Garza-Reyes, J. A., \& Kumar, V. (2014). The impact of lean methods and tools on the operational performance of manufacturing organizations. International Journal of Production Research, 18(52), 5346-5366. http://dx.doi.org/10.1080/00207543.2014.903348.

Bhamu, J., \& Sangwan, K. S. (2014). Lean manufacturing: literature review and research issues. International Journal of Operations \& Production Management, 34(7), 876-940. http://dx.doi.org/10.1108/lJOPM-08-2012-0315.

Calarge, F. A., Satolo, E. G., Pereira, F. H., \& Diaz, E. C. (2012). Evaluation of Lean Production System by using SAE J4000 standard: case study in Brazilian and Spanish automotive component manufacturing organizations. African Journal of Business Management, 6(49), 11839-11850. http://dx.doi.org/10.5897/AJBM12.465.

Cardozo, E. R., Rodríguez, C., \& Guaita, W. (2011). Las pequeñas y medianas empresas agroalimentarias en venezuela y el desarrollo sustentable: enfoque basado en los principios de manufactura esbelta. Información Tecnológica, 22(5), 39-48. http://dx.doi.org/10.4067/S0718-07642011000500006.

Cassell, C., \& Symon, G. (2004). Essential guide to qualitative methods in organizational research. London: Sage Publications. http://dx.doi.org/10.4135/9781446280119.

Chiarini, A. (2014). Sustainable manufacturing-greening processes using specific Lean Production tools: an empirical observation from European motorcycle component manufacturers. Journal of Cleaner Production, 85, 226-233. http://dx.doi.org/10.1016/j.jclepro.2014.07.080.

Chiarini, A., \& Vagnoni, E. (2014). World-class manufacturing by Fiat. Comparison with Toyota Production System from a strategic management, management accounting, operations management and performance measurement dimension. International Journal of Production Research, 53(2), 590-606. http://dx.doi.org/10.1080/00207543.2014.958596.

Claire, J., Duncan, A., \& Niamh, C. (2014). Innovation and skills: implications for the agri-food sector. Education + Training, 56(4), 271-286. http://dx.doi.org/10.1108/ET-11-2012-0122.

Cox, A., Chicksand, D., \& Palmer, M. (2007). Stairways to heaven or treadmills to oblivion? Creating sustainable strategies in red meat supply chains. British Food Journal, 109(9), 689-720. http://dx.doi.org/10.1108/00070700710780689.

Dora, M., \& Gellynck, X. (2015). House of lean for food processing SMEs. Trends in Food Science \& Technology, 44(2), 272-281. http://dx.doi.org/10.1016/j.tifs.2015.03.008.

Dora, M., Kumar, M., Van Goubergen, D., Molnar, A., \& Gellynck, X. (2013). Operational performance and critical success factors of lean manufacturing in European food processing SMEs. Trends in Food Science \& Technology, 31(2), 156-164. http://dx.doi.org/10.1016/j.tifs.2013.03.002.

Feld, W. M. (2001). Lean manufacturing: tools, techniques, and how to use them. Florida: CRC Press.

Forrester, P. L., Shimizu, U. K., Soriano-Meier, H., Garza-Reyes, J. A., \& Basso, F. C. L. (2010). Lean production, market share and value creation in the agricultural machinery sector in Brazil. Journal of Manufacturing Technology Management, 21(7), 853-871. http://dx.doi.org/10.1108/17410381011077955.

Gunderson, M. A., Boehlje, M. D., Neves, M. F., \& Sonka, S. T. (2014). Agribusiness organization and management. In N. K. V. Alfen. Encyclopedia of agriculture and food systems (pp. 51-70). London: Academic Press. http://dx.doi.org/10.1016/B978-0-44452512-3.00117-0. 
Hu, Q., Mason, R., Williams, S. J., \& Found, P. (2015). Lean implementation within SMEs: a literature review. Journal of Manufacturing Technology Management, 26(7), 980-1012. http://dx.doi.org/10.1108/JMTM-02-2014-0013.

Karim, A., \& Arif-Uz-Zaman, K. (2013). A methodology for effective implementation of lean strategies and its performance evaluation in manufacturing organizations. Business Process Management Journal, 19(1), 169-196. http://dx.doi.org/10.1108/14637151311294912.

Kumar, R. (2014). Research methodology: a step-by-step guide for beginners. London: Sage Publications.

Liker, J. (2003). The Toyota way: 14 management principles from the world's greatest manufacturer. New York: McGraw Hill Professional.

Lucato, W. C., Calarge, F. A., Loureiro, M., Jr., \& Calado, R. D. (2014). Performance evaluation of lean manufacturing implementation in Brazil. International Journal of Productivity and Performance Management, 63(5), 529-549. http://dx.doi.org/10.1108/IJPPM-04-2013-0085.

Marodin, G. A., \& Saurin, T. A. (2013). Implementing lean production systems: research areas and opportunities for future studies. International Journal of Production Research, 51(22), 6663-6680. http://dx.doi.org/10.1080/00207543.2013.826831.

Ohno, T. (1988). Toyota production system: beyond large scale production. Cambridge: Productivity PR.

Pakdil, F., \& Leonard, K. M. (2014). Criteria for a lean organisation: development of a lean assessment tool. International Journal of Production Research, 52(15), 4587-4607. http://dx.doi.org/10.1080/00207543.2013.879614.

Perez, C., Castro, R., Simons, D., \& Gimenez, G. (2010). Development of lean supply chains: a case study of the Catalan pork sector. Supply Chain Management, 15(1), 55-68. http://dx.doi.org/10.1108/13598541011018120.

Pettersen, J. (2009). Defining lean production: some conceptual and practical issues. The TQM Journal, 21(2), 127-142. http://dx.doi.org/10.1108/17542730910938137.

Savic, B., Vasiljevic, Z., \& Djordjevic, D. (2014). Strategic cost management as instrument for improving competitiveness of agribusiness complex. Ekonomika Poljoprivrede, 61(4), 10051020. http://dx.doi.org/10.5937/ekoPolj1404005S.

Sharma, V., Dixit, A. R., \& Qadri, M. A. (2015). Impact of lean practices on performance measures in context to Indian machine tool industry. Journal of Manufacturing Technology Management, 26(8), 1218-1242. http://dx.doi.org/10.1108/JMTM-11-2014-0118.

Shingo, S. (1989). A study of the toyota production system: from an industrial engineering viewpoint. Florida: CRC Press.

Silva, V. C. O. (2006). Análise de casos de implementação de Produção Enxuta em empresas brasileiras de máquinas e implementos agrícolas (Dissertação de mestrado). Escola de Engenharia de São Carlos, Universidade de São Paulo, São Carlos. http://dx.doi.org/10.11606/D.18.2006.tde-07062006-120148.

Simons, D., \& Taylor, D. (2007). Lean thinking in the UK red meat industry: a systems and contingency approach. International Journal of Production Economics, 106(1), 70-81. http://dx.doi.org/10.1016/j.ijpe.2006.04.003.

Simons, D., \& Zokaei, K. (2005). Application of lean paradigm in red meat processing. British Food Journal, 107(4), 192-211. http://dx.doi.org/10.1108/00070700510589495.

Stone, K. B. (2012). Four decades of lean: a systematic literature review. International Journal of Lean Six Sigma, 3(2), 112-132. http://dx.doi.org/10.1108/20401461211243702.

Talip, N. F., Hussin, M. S., Hadi, H., \& Zailani, Z. A. (2011). The study of manufacturing considerations of fishery product. International Journal of Engineering Science and Technology, 3(5), 4474-4478. 
Tanco, M., Santos, J., Rodriguez, J. L., \& Reich, J. (2013). Applying lean techniques to nougat fabrication: a seasonal case study. International Journal of Advanced Manufacturing Technology, 68(5-8), 1639-1654. http://dx.doi.org/10.1007/s00170-013-4960-7.

Taylor, D. H. (2005). Value chain analysis: an approach to supply chain improvement in agrifood chains. International Journal of Physical Distribution \& Logistics Management, 35(10), 744-761. http://dx.doi.org/10.1108/09600030510634599.

Taylor, D. H. (2006). Strategic considerations in the development of lean agri-food supply chains: a case study of the UK pork sector. Supply Chain Management, 11(3), 271-280. http://dx.doi.org/10.1108/13598540610662185.

Tomazela, M., Daniel, L. A., \& Ferreira, C. (2010). Administração limpa e enxuta em sistemas hidráulicos de colhedoras de cana-de-açúcar. Engenharia Agrícola, 30(2), 358-366. http://dx.doi.org/10.1590/S0100-69162010000200018.

Vamsi Krishna Jasti, N., \& Kodali, R. (2014). A literature review of empirical research methodology in lean manufacturing. International Journal of Operations \& Production Management, 34(8), 1080-1122. http://dx.doi.org/10.1108/IJOPM-04-2012-0169.

Vinodh, S., Somanaathan, M., \& Arvind, K. R. (2013). Development of value stream map for achieving leanness in a manufacturing organization. Journal of Engineering, Design and Technology, 11(2), 129-141. http://dx.doi.org/10.1108/JEDT-01-2010-0007.

Voss, C., Tsikriktsis, N., \& Frohlich, M. (2002). Case research in operations management. International Journal of Operations \& Production Management, 22(2), 195-219. http://dx.doi.org/10.1108/01443570210414329.

Walter, O. M. F. C., Tubino, D. F. (2013). Assessment methods of lean manufacturing: literature review and classification. Gestão \& Produção, 20(1), 23-45. http://dx.doi.org/10.1590/S0104-530X2013000100003.

Wikner, J., \& Rudberg, M. (2005). Integrating production and engineering perspectives on the customer order decoupling point. International Journal of Operations \& Production Management, 25(7), 623-641. http://dx.doi.org/10.1108/01443570510605072.

Womack, J. P., Jones, D. T., \& Roos, D. (2008). The machine that changed the world. New York: Simon and Schuster.

Xie, X., \& Li, J. (2012). Modeling, analysis and continuous improvement of food production systems: a case study at a meat shaving and packaging line. Journal of Food Engineering, 113(2), 344-350. http://dx.doi.org/10.1016/j.jfoodeng.2012.05.022.

Yin, R. K. (2013). Case study research: design and methods. London: Sage Publications.

Zhang, Z. G., Kim, I., Springer, M., Cai, G. G., \& Yu, Y. (2013). Dynamic pooling of make-tostock and make-to-order operations. International Journal of Production Economics, 144(1), 44-56. http://dx.doi.org/10.1016/j.ijpe.2013.01.012.

Zylberstajn, D. (2013). Administração de sistemas de base agrícola: análise de fatores críticos. Revista de Administração (São Paulo), 48(2), 203-207. http://dx.doi.org/10.5700/rausp1082. 